\title{
Effects of Temperature on Malaria Prevalence in Taraba State, Nigeria
}

\section{J. JOSEPH, B.E. WAMA, V.Y. AKWA AND A.A. BATURE}

See end of the paper for authors' affiliation

Correspondence to :

\section{J. JOSEPH}

Department of Biological

Science, Taraba State

University, JALINGO,

NIGERIA

Email : jonathanjoseph930@ gmail.com

\section{KEY WORDS :}

Seasonal timing, Malaria morbidity, Control

\begin{abstract}
This study investigated the effects of abiotic factors on malaria parasite prevalence, morbidity in Taraba state, Nigeria. Using a retrospective study design, the study relied on secondary data obtained from Meteorological Station Taraba State and Health facilities from 2005-2014. The research findings showed that temperature greatly influence malaria transmission. The effect of temperature on the duration of the sporogonic cycle of the malaria parasite and vector survival is particularly important. From 2005-2014 were $1885.80 \mathrm{~mm}$, per 1000 mean malaria morbidity was 228.90 . Years with peak malaria morbidities (years 2006, 2011 and 2014) had least annual rainfalls (1488.20$1677.00 \mathrm{~mm})$. Monthly malaria morbidity had a significantly negative linear relationship with rainfall ( $\mathrm{r}$ $=-0.827, \mathrm{p}=0.001)$. Malaria morbidity for the decade increased at rates 0.298 per cent. This study provide information on the malaria situation in Taraba State which will be useful to the National Malaria Control Programmes and public health service providers in formulating policies that may promote the mitigation of malaria in Taraba State, Nigeria.
\end{abstract}

How to cite this paper: Joseph, J., Wama, B.E., Akwa, V. Y. and Bature, A. A.(2017). Effects of Temperature on Malaria Prevalence in Taraba State, Nigeria. Internat. J. Med. Sci., 10(1\&2) : 7-13, DOI : 10.15740/HAS/ IJMS/10.1and2/7-13.
Paper History : Received : 02.08.2017; Revised : 12.09.2017; Accepted : 22.09.2017 